\title{
REVITALISASI PEMBERDAYAAN BUDAYA KARAKTER NUANSA RELIGIUSTIK DALAM MEMBENTUK PERILAKU PEKERTI SANTRI
}

\author{
Fathor Rozi \\ Universitas Nurul Jadid \\ fathorrozi330@gmail.com \\ Innani Kholidatul Jannah \\ Universitas Nurul Jadid \\ innanikholida01@gmail.com
}

\begin{abstract}
This writing aims to present a religious planting in shaping santri-like behavior. In shaping the character behavior of students, cultivation is very necessary. This research uses a qualitative approach with a type of case study. The results showed that the existence of a religious activity structure at the pesantren, such as the tahajjut prayer, dhuha prayer, fardhu prayer in congregation, and many other activities. By getting used to these activities, it becomes a shield (medicine) for every santri in forming a santri-like behavior.
\end{abstract}

Keyword: Character, Religious, Morality

\section{Pendahuluan}

Semakin berkembangnya zaman di era modern ini kehidupan makhluk dibumi terutamanya manusia semakin dinamis, hal semuanya dikarenakan perihal penemuan baru baik dari aspek ilmu pengetahuan dan 
teknologi. Dengan memasuki kehidupan baru dan jalan globalisasi saat ini serta pada masa mendatang, yang mana semuanya ditandai dengan pengetahuan dan profesional, maka kami menduga bahwasanya dengan memasuki kehidupan baru banyak orang tidak memeperdulikan tentang moral dan agama baik dalam kehidupannya sendiri maupun bermasyarakat. Kurangnya moral tersebut menimbulkan suatu tingkah laku kurang baik sehingga dengan timbulnya hal tersebut membuat seseorang itu senang akan dunia, sebab dalam kehidupan banyak konkurensi serta perebutan kesempatan yang bertujuan meraih sebuah keuntungan kesenangan dunia ${ }^{1}$.

Dengan demikian maka menanamkan suatu karakter bernuansa relegius sangat penting agar tercipta manusia yang beriman, bertaqwa kepada Allah SWT dan berkhlak baik. Membina akhlak/karakter baik kepada anak menurut al-Ghazali saat ini sangat dibutuhkan terutama dizaman modern dengan dihadapi masalah moral dan akhlak kurang baik, yang mana semua hal tersebut jika dibiarkan begitu saja maka akan menghancurkan suatu insan sebagai penerus bangsa ${ }^{2}$. Ada beberapa hal dalam dunia Pendidikan sering kali terjadi sehingga membuat miris, perkelahian, pergaulan bebas, remaja yang masih sekolah bertingkah laku kurang sopan terhadap guru, seorang pelajar terlibat dalam kasus hal-hal yang tidak sepantasnya (narkoba).

Dengan banyaknya permasalahan serta krisis moral yang terjadi pada remaja saat ini, orang tua merupakan orang pertama paling khawatir jika mengetahui anaknya mempunyai tingkah laku kurang baik ${ }^{3}$. Maka dari itu, berdirinya pondok pesantren merupakan suatu keuntungan bagi orang tua untuk mendidik anaknya di pesantren agar bisa melindungi generasi muda yang ber etika. Tidak hanya itu saja, pesantren juga mempunyai peran yang sangat penting dalam kehidupan masyarakat terkhususkan suatu hal yang bersifat keagamaan. Kehidupan dipesantren sang kyai dan buk nyai sebagai figur sentral yang telah menyumbangkan tenaga dan pikirannya dalam

${ }^{1}$ Lailatul Fitriyah and Erfi Fitri Wahyuni, 'HANDLING SPIRITUALISM SEBAGAI KONTROL DIRI PADA REMAJA DI PONDOK PESANTREN', Jurnal Islam Nusantara, 4.1 (2020), 1-16.

2 Abd Khaliq, 'PENDIDIKAN KARAKTER DALAM PERSPEKTIF KITAB AYYUHAL WALAD; KONSTRUKSI PEMIKIRAN IMAM AL-GHAZALI', Al-Ibrah, 2.1 (2017), 89-112.

${ }^{3}$ Hasan Baharun and Mahmudah, 'KONSTRUKSI PENDIDIKAN KARAKTER DI MADRASAH BERBASIS PESANTREN', Jurnal MUDARRISUNA, 8.1 (2018), 149_ 173.

18 Muróbbî: Jurnal Ilmu Pendidikan 
mendidik santrinya ${ }^{4}$. Meski demikian, adanya permasalahan di pesantren menjadi hambatan, seperti halnya moral dalam diri santri kurang baik. Oleh sebab itu penanaman karakter bersifat religious secara terstruktur dan kokoh merupakan hal sangat penting diterapkan kepada santri di pondok pesantren dengan menggunakan metode pembiasaan yang baik. Santri dibiasakan dengan melakukan hal positif sehingga akan terbiasa ${ }^{5}$. Diharapkan dengan adanya penanaman tersebut santri bisa mengamalkannya dalam kehidupan setiap harinya dan membentuk makhluk yang bertaqwa, yakni mematuhi apa yang diperintahkan Allah SWT dalam melaksanakan ibadah serta memelihara dan mengembangkan bakat yang ada pada diri santri serta terbentuk insanul kamil yang bermoral dan berkarakter islami ${ }^{6}$.

Kasus yang terjadi di Pesantren Al-Islam Lamongan Jawa Timur Indonesia menunjukkan bahwa karakter pemikiran kyai dan pengasuh pesantren yang dirumuskan dalam khiththah Pesantren yaitu terbentuknya generasi rabbani yang memiliki keimanan dan keikhlasan sebagai landasan amal, memahami cara beribadah yang benar, memiliki akhlak yang terpuji, memiliki spiritualitas yang baik, memiliki wawasan keilmuan yang luas, memiliki fisik yang sehat dan kuat, serta memiliki kesiapan untuk berdakwah ${ }^{7}$.

Berdasarkan penelitian terdahulu yang dilakukan Moh.Dulkiah tentang "Model pengembangan karakter santri di pesantren persis 67 benda tasikmalaya jawa barat", hasil penelitian menunjukkan bahwasanya dalam mengatasi krisis moral santri dilakukan dengan beberapa pola diantaranya: pengembangan karakter santri yang terletak pada saat proses pengajaran, pembiasaan, dan suatu aturan (takziran). Aspek pengajaran ini tidak terletak pada pengembangan kurikulum saja yang menggabungkan antara kurikulum kementerian agama dan kementerian nasional. Aspek

\footnotetext{
${ }^{4}$ Setyawati and Zakiyah, PELATIHAN PENCEGAHAN MEROSOTNYA MORAL SANTRI MELALUI BELAJAR SEKSUALITAS DENGAN KAJIAN KITAB KUNING DAN KESEHATAN REPRODUKSI REMAJA DI PONDOK PESANTREN ROMLAH ASSOMADIYAH KECAMATAN CILONGOK', ISLAMADINA, XVII.2 (2016), 21-30.

${ }^{5}$ Saeful Anam and Muhammad Sidiq Jaelani, 'ISLAMIC SCHOOL CULTURE DAN UPAYA MENANAMKAN NILAI-NILAI RELIGIOUS DI SMP ISLAMIC QON GRESIK', 2018, 551-560.

${ }^{6} \mathrm{H}$. Abdul Rahman, 'PENDIDIKAN AGAMA ISLAM DAN PENDIDIKAN ISLAM - 'TINJAUAN EPISTEMOLOGI DAN ISI - MATERI’, JURNAL EKSIS, 8.1 (2012), 2053-2059.

7 Muhammad Hambal, 'Pembentukan Karakter Rabbani Di Pesantren Al-Islam Lamongan Jawa Timur Indonesia', Jurnal Tadarus, 8.1 (2019), 74-82.
} 
pembiasaan, pada aspek pembiasaan ini santri diupayakan membiasakan karakter/akhlak dalam setiap harinya untuk memiliki sifat yang bermoral, mengajarkan sikap dan tingkah laku yang disiplin. Aspek penegakan aturan, pada aspek ini penegakan suatu aturan dalam bentuk fisik guna memmberikan motivasi agar lebih baik lagi kedepannya ${ }^{8}$.

Demikian itu program penanaman karakter nuansa religius yang telah diterapkan di Pondok Pesantren Nurul Jadid Paiton Probolinggo khususnya wilayah Fatimatuzzahro' yang telah diterapkan pada santri dengan tujuan mencipatakan suatu perilaku yang sesuai dengan aturanaturan agama, sehingga adanya permasalahan pada setiap seseorang/santri dapat diatasi dengan adanya penanaman karakter tersebut ${ }^{9}$. Oleh sebab itu, diadakannya penanaman karakter nuansa religius yang diterapkan di Wilayah Fatimatuzzahro' merupakan suatu usaha dalam membentuk santri yang bermoral dan berakhlak baik. Selain itu penanaman karakter yang bersifat religius juga mencegah dari perilaku tidak baik yang timbul dari teman sebaya atau keluarga. Maka dari itu, pesantren merupakan tempat untuk memperlebih dalam lagi dalam mencari ilmu pengetahuan untuk memperbaiki suatu tingkah laku yang kurang baik.

Adapun keunikan dari penulisan jurnal ini peneliti ingin memaparkan salah satu Pondok Pesantren Nurul Jadid Paiton Probolinggo khususnya Wilayah Fatimatuzzahro', yang mana pensantren tersebut merupakan sebuah pesantren modern sehingga banyak masyarakat memondok kan putra putrinya disana untuk menimba ilmu agama. Dengan banyaknya santri di Pondok Pesantren Nurul Jadid yang datang dari berbagai kalangan berbeda-beda sehingga moral setiap santri tidak sama, Pondok Pesantren Nurul Jadid khusunya Wilayah Fatimatuzzahro' membuat sebuah peraturan yang mana peraturan tersebut langsung dari pemangku sendiri, adanya peraturan ini agar setiap santri terbiasa melakukan semua kegiatan, seperti halnya jika shalat dirumah shalat sendiri maka di pondok shalat berjamaah. Oleh sebab itu, Pondok Pesantren Nurul Jadid terkhusus Wilayah Fatimatuzzahro' menerapkan Pendidikan religius agar tercipta suatu karakter yang baik. Terdapat beberapa kegiatan yang ada di Pondok Pesantren Nurul Jadid khususnya

8 Moh Dulkiah and Muhammad Dachlan, 'MODEL PENGEMBANGAN KARAKTER SANTRI DI PESANTREN PERSIS 67 BENDA TASIKMALAYA JAWA BARAT', Jurnal Al-Qalam, 24.1 (2018), 177-188.

9 Marzuki and Pratiwi Istifany Haq, 'PENANAMAN NILAI-NILAI KARAKTER RELIGIUS DAN KARAKTER KEBANGSAAN DI MADRASAH TSANAWIYAH AL FALAH JATINANGOR SUMEDANG', Jurnal Pendidikan Karakter, VIII.1 (2018), 84-94. 
Wilayah Fatimatuzzahro' diantaranya adalah shalat berjamaah, pengajian kitab, sorogan, ziaroh makbaroh pengasuh, dan banyak lagi lainnya. Jika santri sudah terbiasa melakukan semua kegiatan itu maka akan terciptalah tingkah laku yang baik terhadap masing-masing santri.

Melalui penelitian ini dengan menggunakan jenis penelitian lapangan (field research) dengan menggunakan pendekatan deskriptif kualitatif. Teknik analisisnya menggunakan analisis isi yang mana pengumpulan data berupa hasil wawancara dan observasi. Analisis yang penulis ambil dilakukan secara sistematis, yang mana semua itu dimulai dari penyajian data, reduksi data dan berakhir dengan penarikan kesimpulan. Adanya penelitian ini peneliti ingin mengetahui bagaimana penanaman karakter nuansa religius dalam menanggulangi penyakit moral santri. Dalam hal ini sebagaimana telah diketahui bahwa kondisi moral santri kurang baik. Semua itu bisa dilihat ketika santri melanggar peraturan yang ada di pondok, salah satunya ialah keluar tanpa izin, urak-urakan kurang sopan kepada yang lebih tua dll. Adanya semua ini sudah terbukti bahwa penanaman karakter yang bersifat religius sangat penting terhadap diri santri agar mempunyai akhlak yang baik.

Selain penanaman karakter yang dilakukan pesantren, teman juga sangat berperan untuk merubah sikap santri yang kurang baik. Teman tidak hanya mendengarkan keluh kesah yang kita alami melainkan juga orang yang menuntun kita menuju jalan yang di ridhai Allah SWT. Adanya seorang teman juga bisa membentuk karakter yang baik. Tidak hanya itu, apa-apa yang dilakukan teman maka kita akan mengikutinya, baik itu berupa perbuatan yang baik atau sebaliknya (buruk).

Maka dari itu, dengan adanya Pendidikan religius yang diterapkan dipesantren Nurul Jadid khususnya Wilayah Fatimatuzzahro' ini agar dalam diri setiap santri terbentuk sebuah karakter yang baik. Dalam hal ini penanaman karakter bersifat religius yang diterapkan pesantren agar supaya karakter setiap santri itu bersifat baik, sehingga dengan tertanamnya karakter yang baik maka akan mencegah dari tingkah laku kurang baik terhadap diri setiap santri.

\section{Konseptual Karakter Perspektif Universal}

Secara etimologis, kata karakter ini merupakan suatu tabi'at, watak, sifat kejiwaan, akhlak atau budi pekerti untuk membedakan orang satu dengan lainnya. Dalam Bahasa Inggris, karakter (character) yang artinya distinctive differentiating mark, suatu tanda yang membedakan seseorang 
dengan orang lain ${ }^{10}$. Sebenarnya kata karakter ini diambil dari Bahasa Yunani, yaitu charassein, yang artinya mengukir. Sedangkan secara harfiyah, karakter adalah mental yang bermutu, moral, kekuatan suatu tingkah laku, nama atau reputasi. Manusia sendiri mempunyai dua aspek, yaitu: aspek fisik dan aspek psikis (jiwa). Aspek psikislah yang memunculkan suatu karakter pada diri seseorang sehingga dipraktikkan dalam bentuk tingkah laku. Dengan begitu tingkah laku yang dilakukan seseorang itu tidak luput dari dorongan suatu jiwa sehingga seseorang dalam melakukan suatu tindakan kebaikan dan kejahatan itu didasari dan diawali dari niat atau dorongan motivasi dari jiwa seseorang sendiri ${ }^{11}$.

Agama islam mengatakan bahwasanya karakter merupakan inti dari pendidikan Islam yang kita kenal dengan sebutan Pendidikan akhlak. Pendidikan akhlak ini mengantarkan seseorang untuk bersikap dan berperilaku sesuai dengan karakter Islam. Raharjo mengartikan Pendidikan karakter itu sebagai suatu proses Pendidikan secara holistik yang menghubungkan antara moral dan ranah sosial dalam kehidupan seseorang sebagai suatu fondasi agar tebentuklah generasi yang berkualitas yang mampu hidup mandiri serta memiliki prinsip sendiri dan bisa dipertanggung jawabkan ${ }^{12}$.

Menurut Doni Koesoema, karakter hampir sama dengan kepribadian. Dengan demikian kepribadian sendiri dianggap sebagai suatu ciri, karakteristik, gaya, atau sifat dari diri orang itu sendiri yang mana semua itu bisa di dapatkan dari lingkungan ${ }^{13}$. Akan tetapi menurut penulis sendiri kepribadian seseorang itu bukanlah bentuk dari suatu karakter karena dalam diri seseorang itu terdapat kepribadian yang berbeda-beda. Oleh sebab itu, dari bebagai macam tipe kepribadian mempunyai kelemahan dan kelebihannya ${ }^{14}$.

Musfiroh; menyatakan, karakter merupakan suatu rangkaian sikap seseorang dalam berperilaku (behavior), motivasi (motivation) yang mana dalam hal seseorang terdorong melakukan suatu perbuatan karena dengan

\footnotetext{
10 Muhtar Zaini Dahlan, 'INTERNALISASI PENDIDIKAN KARAKTER', FALASIFA, 7.1 (2016), 155-172.

11 Chusnul Muali and Putri Naily Rohmatika, 'KAJIAN REFLEKSI TEORI PENGEMBANGAN KARAKTER ANAK MELALUI PEMBELAJARAN AGAMA PERSPEKTIF ALBERT BANDURA', FIKROTUNA; Jurnal Pendidikan Dan Manajemen Islam, 9.1 (2019), 1032-1052.

${ }^{12}$ Chusnul Muali, 'RASIONALITAS KONSEPSI BUDAYA NUSANTARA DALAM MENGGAGAS PENDIDIKAN KARAKTER BANGSA MULTIKULTURAL', Jurnal Islam Nusantara, 1.1 (2017), 105-117.

${ }^{13}$ Saiful Bahri, 'IMPLEMENTASI PENDIDIKAN KARAKTER DALAM

MENGATASI KRISIS MORAL DI SEKOLAH', TA'ALLUM, 3.1 (2015), 57-76.

14 Anam and Jaelani.
} 
adanya motivasi, dan keterampilan (skill) yang meliputi keinginan dalam diri seseorang untuk melakukan hal-hal yang baik ${ }^{15}$. Dalam hal ini, karakter dapat dikembangkan melalui sebuah pengetahuan (knowing), bertindak (acting), dan menuju kebiasaan (babit). Karakter bukan hanya pengetahuan saja, melainkan juga perlu adanya perbuatan dan kebiasaan dalam berbuat sesuatu. Maka atas dasar itulah, seseorang yang hanya mempunyai pengetahuan kebaikan saja belum tentu bisa melakukan sesuatu dengan pengetahuannya tanpa berlatih melakukan kebaikan.

Karakter sendiri sangat berkaitan sekali dengan kekuatan moral, berkonotasi positif, bukan netral ${ }^{16}$. Jadi, orang berkarakter adalah orang yang mempunyai kualitas moral positif. Oleh karena itu, pesantren membangun sebuah karakter, yang mana karakter sendiri mengandung sebuah arti suatu sifat atau gambaran perilaku seseorang yang didasari atau berkaitan dengan moral positif atau baik, melainkan bukan negatif atau buruk ${ }^{17}$. Karakter juga merupakan nilai perilaku yang ditunjukkan seseorang, yang berhubungan dengan tuhan, dirinya sendiri, sesama manusia, dan lingkungannya yang terbentuk dalam pola pikir, perasaan, perkataan, sikap, serta sesuatu yang didasari atas aturan dan norma agama, sosial, budaya, hukum, adat istiadat, dan estetika.

Menurut Foerster karakter mempunyai salah satu kriteria utama dengan "character strength" adalah karakter mempunyai peluang (kontribusi) sangat besar untuk mewujudkan kemampuan dan cita-cita seseorang dalam membangun sebuah kehidupaan baik, bermanfaat bagi dirinya, orang lain, dan negara. Terdapat empat ciri dasar karakter, dengan meliputi hal-hal berikut.

Keteraturan interior, dalam hal ini semua perbuatan dapat diukur dengan hierarki nilai. Nilai merupakan suatu pedoman normatif dalam setiap tindakan. Koherensi, koherensi memberikan keberanian kepada seseorang agar tetap berpegang teguh pada prinsip, tidak mudah terhasut pada situasi baru dan beresiko. Koherensi juga memrupakan suatu dasar dalam membangun rasa percaya yang satu dengan lainnya. Jika koherensi ini tidak ada maka akan meruntuhkan kredibilitas seseorang. Otonomi, seseorang akan menanamkan suatu aturan dari luar sampai menjadi nilainilai bagi diri pribadi orang tersebut. Semua ini bisa kita lihat melewati penilain atas keputusan pribadi tanpa pengaruh atau desakan dari pihak

15 Didik Suhardi, 'PERAN SMP BERBASIS PESANTREN SEBAGAI UPAYA PENANAMAN PENDIDIKAN KARAKTER KEPADA GENERASI BANGSA', Jurnal Pendidikan Karakter, II.3 (2012), 316-328.

${ }^{16}$ Chusnul Muali, Ayyul Fariqoini, and Azizatul Widad, Pembelajaran Konstruktif (Pustaka Nurja, 2019).

${ }^{17}$ Fifi Nofiaturrahmah, 'METODE PENDIDIKAN KARAKTER DI PESANTREN', Pendidikan Agama Islam, XI.1 (2014), 201-216. 
lain. Keteguhan dan kesetiaan, keteguhan ini merupakan daya tahan seseorang guna mengingini apa yang dipandang baik. Kesetiaan merupakan dasar suatu penghornatan keterikatan (komitmen) yang dipilih.

Foerster mengatakan dengan keempat kematangan karakter ini, maka manusia akan melewati tahap individualitas menuju personalitas. "Orang modern selalu menyamakan (mencampur aduk) antara individualitas dan personalitas, antara aku alami dan aku rohani, antara independensi eksterior dan interior". Karakter inilah yang menentukan forma seorang pribadi dalam segala tindakannya ".

Lickona mendefinisikan Pendidikan karakter sebagai salah satu usaha dalam membantu seseorang memahami, peduli serta bertindak dengan berdasarkan nilai-nilai etika. Menurut Lickona karakter berkaitan dengan konsep moral (moral knowning), sikap moral (moral felling), dan perilaku moral (moral behavior). Karakter juga memerlukan proses Pendidikan penghayatan, pelatihan dan pembiasaan. Berdasarkan bagan yang disebutkan diatas menyatakan bahwa karakter baik akan didukung oleh pengetahuan tentang kebaikan, ingin berbuat baik serta melakukan hal-hal yang baik pula. Adapun bagan dibawah ini merupakan bagan keterkaitan dari tiga kerangka pikir ini ${ }^{18}$.
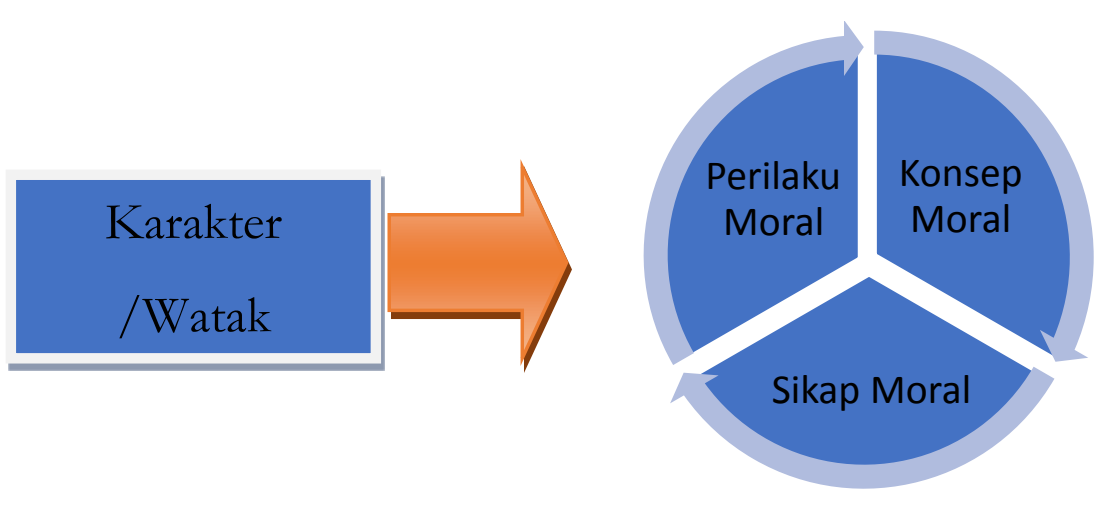

Gambar 1

Kaitannya Kerangka antara Komponen Moral dalam Rangka Membentuk suatu Karakter yang Baik Menurut Lickona

Dari beberapa pemaparan argumen diatas maka dapat disimpulkan bahwa, karakter ini merupakan suatu tingkah laku atau sifat seseorang, yang mana semua itu bisa dinilai dari karakter setiap masing-masing orang. Karakter juga merupakan suatu pengetahuan kebaikan, akan tetapi jika

${ }^{18}$ H.A. Rodli Makmun, "PEMBENTUKAN KARAKTER BERBASIS PENDIDIKAN PESANTREN : Studi Di Pondok Pesantren Tradisional Dan Modern Di Kabupaten Ponorogo," Cendekia 12, no. 2 (2014): 212-237. 
suatu pengetahuan kebaikan itu tidak dilatih belum tentu bisa melakukan pengetahuan. Karena, Jika karakter seseorang itu jelek maka tingkah lakunya akan buruk begitu juga sebaliknya jika karakter orang tersebut baik maka apa yang diperbuatnya itu suatu perbuatan yang baik.

Maka dari itu Pendidikan karakter tidak hanya mengajarkan mana yang benar dan mana yang salah. Melainkan, Pendidikan karakter juga akan menanamkan pembiasaan dalam kehidupan sehari-hari santri terkait hal yang benar dan salah sehingga santri akan paham (kognitif), mampu merasakan (afektif) apa yang dinilai dirinya itu baik sehingga santri akan terbiasa melakukannya (psikomotorik) hal yang baik ${ }^{19}$.

Berdasarkan nilai-nilai dasar pada sembilan pilar karakter di Indonesia, antara lain: (1) Cinta kepada Allah dan semesta beserta isinya; (2) mempunyai tanggung jawab, disiplin, dan mandiri; (3) jujur; (4) takdzim dan sopan; (5) mempunyai rasa kasih sayang, peduli, kerja sama; (6) percaya diri, memiliki daya cipta tinggi (kreatif); (7) adil dalam memimpin; (8) baik dan tawaduk; (9) toleransi, cinta damai, dan persatuan ${ }^{20}$.

\section{Eksistensi Moral dan Pekerti Santri}

Al-Ghazali mendefinisikan kata moral (kbulq) adalah suatu keadaan atau bentuk jiwa yang menjadi sebuah sumber dari sebuah timbulnya perbuatan yang mudah tanpa melalui pemikiran dan suatu usaha. Adapun pengertian jiwa sendiri al-Ghazali menggunakan empat istilah, yaitu al-qalb, al-nafs, al-rub dan al-aq ${ }^{21}$. Empat isitilah ini mempunyai persamaan dan perbedaan arti, jika dilihat dari segi fisik al-qalb merupakan kalbu jasmani, al-rub berarti suatu roh jasmani dan latif, yang berarti hawa nafsu dan al-aql yang artinya ilmu. Pada hakikatnya moral dan sifat seseorang itu bergantung pada jiwa yang ada pada dirinya. Jika jiwa yang berkuasa itu nabbati dan hewani maka moral seseorang akan menyerupai nabbati dan hewani. Begitu juga sebaliknya, jika yang berkuasa jiwa insaniyah maka moral tersebut insan kamil. Jadi, moral merupakan suatu kondisi jiwa yang melahirkan suatu perbuatan tanpa memerlukan suatu pertimbangan dan pikiran.

Moral juga berasal dari Bahasa latin mores yang artinya tata cara dalam kehidupan atau adat istiadat. Penalaran moral menekankan pada suatu

\footnotetext{
${ }^{19}$ Akmal Mundiri and Irma Zahra, 'CORAK REPRESENTASI IDENTITAS USTADZ DALAM PROSES TRANSMISI PENDIDIKAN KARAKTER DI PESANTREN', 2005, 21-35.

${ }^{20}$ Hasan Baharun and Zulfaizah, 'Revitalisasi Pendidikan Agama Dalam Pembentukan Karakter Peserta Didik Di Madrasah’, ELEMENTARY, 6.1 (2018), 43-62.

${ }^{21}$ Feriska Listrianti and Fitriana, 'PENDIDIKAN AKHLAK PERSPEKTIF ALGHAZALI DALAM MENGATASI RATIONAL HEDONISM DI MTS NEGERI 1 PROBOLINGGO', RIS AL AH Jurnal Pendidikan Dan Studi Islam, 6.1 (2020), 100-116.
} 
alasan mengapa suatu tindakan itu dilakukan, sehingga dapat kita nilai apakah tindakan tersebut baik atau buruk. Dengan semakin menurunnya moral dikalangan remaja saat ini dianggap sebuah cerminan akan kurang berhasilnya dunia Pendidikan di era globalisasi. Moral merupakan perubahan dari perasaan, dan suatu perilaku yang benar dan salah. Hal ini ada berdasarkan perkembangan di lingkungan sekitar. Moral secara ekplisit mempunyai hubungan dengan proses sosialisasi individu, karena dengan tidak adanya moral maka manusia tidak dapat bersosial. Maka dari itu, moral menurut al-Ghazali adalah menghilangkan suatu tingkah laku (akhlak) yang buruk dan menanamkan akhlak yang baik ${ }^{22}$.

Dengan terjadinya kejadian yang tidak di inginkan di dunia Pesantren sering terjadi santri terlibat dalam kasus sepertihalnya perilaku amoral, kabur, urak-urakan, kurang sopan terhadap guru, tidak berjama'ah dll. Berangkat dari fakta yang ada, maka begitu pentingnya perilaku pekerti santri agar dibina dari sejak dini. Dengan berdirinya pondok pesantren sebagai tempat dalam mencari ilmu agama, maka hal tersebut merupakan satu solusi yang efektif dalam mengatasi permasalahan yang ada pada remaja saat ini. Oleh karena itu, pesantren yang megajarkan tentang Pendidikan karakter dalam membentuk suatu karakter yang baik ${ }^{23}$.

Dalam hal ini problematika atau yang biasa disebut dengan masalah yang artinya terdapat ketidak seimbangan antara harapan dengan kenyataan. Jadi problemtika di pesantren adalah suatu masalah yang terjadi pada santri sehingga permasalahan tersebut tidak sesuai dengan kenyataan yang diharapkan pesantren. Problematika perilaku pekerti santri di Pondok Pesantren Nurul Jadid Wilayah Fatimatuzzahro' yakni, pertama faktor teman, teman sangat berpengaruh sekali terhadap perilaku pekerti santri sehingga seorang teman itu bisa membuat kita terjerumus dalam lubang yang tidak di inginkan. Seorang teman tidak hanya membawa dalam hal keburukan saja melainkan juga dalam hal kebaikan. Jadi jika kita berteman dengan orang yang perilakunya buruk maka perilaku kita akan ikut buruk pula, karena seorang teman itu sangat berpengaruh sekali dalam pergaulan seseorang ${ }^{24}$. Seperti halnya jika berteman dengan santri yang sering telat berjama'ah maka kita akan sering telat juga berjama'ah, begitu juga sebaliknya jika kita bersama dengan orang yang rajin maka kita akan menjadi orang yang rajin. Juga bisa dilihat dari tingkah laku teman, jika

\footnotetext{
${ }^{22}$ Didi Supardi, Abdul Ghofar, and Mahbub Nuryadien, 'KONSEP PENDIDIKAN MORAL IMAM AL-GHAZALI DAN RELEVANSINYA DENGAN PENDIDIKAN AGAMA ISLAM DI INDONESIA', JURNAL AL TARBAWI AL HADITS AH, 1.2, $1-9$.

${ }^{23}$ Syaepul Manan, 'PEMBINAAN AKHLAK MULIA MELALUI KETELADANAN DAN PEMBIASAAN', Jurnal Pendidikan Agama Islam-Ta'lim, 15.1 (2017), 49-65.

${ }^{24}$ Baharun and Zulfaizah.
} 
tingkah laku teman kita itu kurang baik, maka tingkah laku kita juga ikut tidak baik.

Melihat fenomena unik yang terjadi pada diri setiap masing-masing santri mulai dari perilaku pekerti dan penyimpangan-penyimpangan yang dilakukan. Contohnya dalam kegiatan yang ada dipesantren, pada umumnya jika seseorang itu bisa membagi waktu dalam berbuat sesuatu maka suatu pelanggaran itu tidak akan timbul pada diri setiap santri sehingga dengan padatnya dan ketatnya suatu kegiatan membuat seseorang itu sulit untuk melakukan suatu pelanggaran ${ }^{25}$.

Dalam membentuk perilaku pekerti santri dengan melalui karakter yang bersifat religius pada santri Pondok Pesantren Nurul Jadid Wilayah Fatimatuzzahro' terdapat faktor pendukung dari pengurus, jika santri melakukan suatu pelanggaran dari beberapa kegiatan yang ada dipesantren maka solusi dari pesantren ialah pengurus akan memberikan suatu hukuman (punismen) pada santri agar dalam diri santri itu terdapat sifat jera, sehingga dengan adanya hukuman tadi santri tidak akan melakukan hal-hal yang akan mengakibatkan dirinya di hukum lagi. Adanya hukuman ini bukan berarti pengurus itu benci atau tidak suka, melainkan semua ini hanya untuk mendidik santri agar dalam dirinya di jauhi dari hal-hal yang tidak baik ${ }^{26}$.

\section{Penanaman Karakter Religiustik Sebagai Penyeimbang Perilaku Pekerti Santri}

Santri sendiri merupakan kata arti adalah orang yang sedang mempelajari ilmu agama islam yang berada dibawah naungan pesantren, atau orang yang sedang beribadah dengan sungguh-sungguh, atau bisa disebut orang saleh. Sebagai seorang santri dituntut untuk memiliki perilaku pekerti yang baik ${ }^{27}$. Oleh karena itu pesantren merupakan salah satu tempat untuk menimbah ilmu Agama dalam syari'at islam. Pesantren juga merupakan Pendidikan islam untuk mendalami dan mengamalkan agama islam dalam kehidupan sehari-hari santri. Sehingga banyak sekali pesantren yang bisa menjadi panutan dalam menimba ilmu (mendalami) ajaran islam ${ }^{28}$.

25 Nurotun Mumtahanah, 'PENGEMBANGAN SISTEM PENDIDIKAN PESANTREN DALAM MENINGKATKAN PROFESIONALISME SANTRI', AL HIKMAH Jurnal Studi Keislaman, 5.1 (2015), 55-70.

26 Pasmah Candra, Nelly Marhayati, and Wahyu, 'PENDIDIKAN KARAKTER RELIGIUS DAN TOLERANSI PADA SANTRI PONDOK PESANTREN AL HASANAH BENGKULU', 11.1 (2020), 111-132.

27 Supardi, Ghofar, and Nuryadien.

${ }^{28}$ Tamrin Fathoni, 'PESANTREN DAN PENANAMAN SIKAP ANTI KORUPSI', AL-MANHAJ; Jurnal Hukum Dan Pranata Sosial Islam, 1.1 (2019), 26-42. 
Sebagaimana yang telah kita ketahui bersama Pondok Pesantren Nurul Jadid merupakan salah satu tempat untuk menimbah ilmu agama, pesantren tersebut merupakan salah satu pesantren modern yang terletak di kecamatan Paiton khususnya daerah Probolinggo Jawa Timur. Di pesantren tersebut terdapat beberapa dhalem yang mana kegiatan setiap dhalem itu berbeda-beda. Nama-nama dhalem tersebut diantaranya AzZainiyah, Al-Hasyimiyah, Fatimatuz Zahro', Al-Mawaddah, Al-Latifiyah, dan yang terakhir Zaid bin Tsabit. Dalam hal ini kami ingn mengupas sedikit permasalahan yang ada di wilayah Fatimatuz Zahro', adapun permasalahan yang terjadi ini salah satunya ialah terkait tindakan seorang santri yang tidak sesuai dengan apa yang ditetapkan di pesantren. Maka dari itu, penulis ingin tahu lebih dalam lagi tentang bagaimana cara menanamkan karakter setiap santri yang ada di Wilayah Fatimatuz Zahro'. Dalam hal ini moral kurang baik yang ada pada diri santri akan kami tanamkan dengan karakter yang bersifat religius.

Berdasarkan hasil wawancara dengan Izzatul Fitriyah selaku salah satu pengurus Wilayah Fatimatuzzahro', dengan banyaknya permasalahan yang ada di pesantren khususnya wilayah Fatimatuzzahro' maka perlulah kita menanaman karakter pada setiap santri melaui struktur kegiatan yang ada di wilayah yang mana semua kegiatannya itu bersifat religius (ketuhanan) dengan melalui beberapa tahap: Pertama pembiasaan (habbituasi), dengan membiasakan hal-hal tertentu santri dalam melakukan sesuatu maka kebiasaan tersebut akan mendarah daging, sehingga melakukan suatu hal tidak perlu arahan lagi ${ }^{29}$. Oleh karena itu, penanaman karakter tersebut dimulai dari pelaksanaan shalat tahajjud, shalat dhuha, serta shalat sunnah yang lain lebih ditingkatkan lagi agar setiap santri bisa membiasakan melakukan ibadah shalat sunnah. Seperti halnya shalat dhuha, yang mana shalat dhuha dilaksanakan secara berjama'ah. Adanya suatu peraturan sholat dhuha berjamaah agar setiap santri terbiasa shalat dhuha berjamaah, karena jika santri sudah terbiasa melaksanakan shalat sunnah berjamah maka tidak akan berat untuk melaksanakan shalat secara berjamaah. Shalat dhuha dilakukan secara berjamaah serta tidak lupa pula shalat fardhu yang dipimpin oleh pengurus ubudiyah dan pengurus harian wilayah ${ }^{30}$. Adapun manfaat dari pembiasaan shalat tersebut agar seseoraang itu bisa bersyukur, lebih tawakkal, ikhlas, mengimplementasikan perilaku pekerti sopan seperti mengontrol emosi dan jujur.

29 Ahmad Zakky Mubarok, 'Model Pendekatan Pendidikan Karakter Di Pesantren Terpadu', Ta'dibuna, 8.1 (2019), 134-145.

${ }^{30}$ Hasil wawancara dengan salah satu pengurus Wilayah Fatimatuzzahro', tanggal 15 November 2020 Pukul 08.30 Wib. 
Dalam hal ini Shalat tahajjut juga tidak lupa dilakukan setiap santri pada jam 03:00 wib. Shalat tahajjut merupakan suatu kebaikan untuk mendekatkan diri kepada Allah SWT agar lebih baik lagi serta menumbuhkan suatu yang besifat religius dalam jiwa seseorang. Kemudian dilanjutkan menunggu untuk melaksanakan shalat shubuh berjamaah, terkadang shalat jama'ah langsung dipimpin oleh pengasuh sendiri dan dengan adanya shalat berjamaah bersama pengasuh maka semua itu untuk mengasah setiap santri agar terbiasa melakukan shalat secara berjamaah.

Kedua good example (keteladanan), keteladanan merupakan langkah dalam membentuk akhlak setiap santri, hal tersebut telah dilakukan seorang guru dengan melalui tausiyah, kemudian tausiyah tersebut diamalkan setiap santri agar mempunyai akhlak atau tingkah laku yang baik. Dengan terciptanya akhlak yang baik dapat diterapkan dalam kehidupan setiap hari mereka, serta mampu membedakaan suatu tindakan tersebut baik dimasyarakat maupun dipesantren. Keteladanan yang dilihat santri itu langsung dari pengasuh terkait ketaatan dalam kedisiplinan yang sesuai dengan ajaran Agama. Nilai keteladanan ini juga tercermin dari Rasulullah SAW yang telah disebutkan dalam Al-Qur'an surat Al-Ahzab ayat 21 yang bunyinya ${ }^{31}$ :

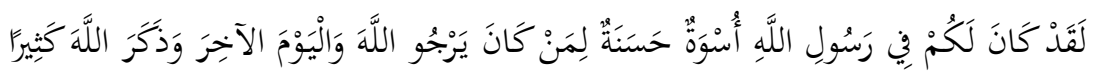
Sesunggubnya telah ada pada (diri) Rasulullah itu suri teladan yang baik bagimu (yaitu) bagi orang yang mengharap (rabmat) Allah dan (kedatangan) hari kiamat dan dia banyak menyebut Allah.

Oleh sebab itu keteladanan seorang guru dapat memberikan suatu dorongan pada santri agar mempunyai akhlak baik yang sesuai dengan tradisional lingkungan pesantren, sehingga menciptakan tingkah laku baik yang sudah tertanam dalam jiwa setiap santri. Tausiyah tersebut merupakan suatu ucapan positif atau pesan dari guru kepada peserta didiknya agar terarah kejalan lebih baik yang sesuai dengan ketentuan dalam suatu wilayah. Dalam hal ini wilayah dapat diartikan suatu lingkup dipesantren, di pesantren nasihat guru lebih dikenal dengan sebutan taushiyah. Taushiyah lebih condong ada dalam pesantren, hal ini terpusat pada Pendidikan akhlak, moral, dan etika santri. Guru akan memberikan taushiyah kepada santri agar dalam dirinya tertanam akhlakul karimah yang diharapkan masyarakat ketika tenjun dimasyarakat. Taushiyah guru dapat menjadi pengingat seorang santri agar mengikuti suatu aturan yang berlaku

31 Miftachul Ulum, "PEMBENTUKAN KARAKTER MELALUI PENDIDIKAN BERBASIS PONDOK PESANTREN,” EV ALUASI 2, no. 2 (2018): 382-397. 
dimanapun mereka berada serta meninggalkan suatu tingkah laku kurang baik. Jika santri mampu mengamalkan dan memanfaatkan tausiyah dari guru maka ia akan menjadi santri husnul karim.

Ketiga hidden kurikulum, Pendidikan dan pengajaran yang ada dipesantren melaui kitab klasik dan madrasah diniyah: Kitab klasik tersebut lebih dikenal dengan kitab kuning dalam meningkatkan ilmu pengetahuan islam. Kitab kuning merupakan tradisi pesantren dalam mengkaji dan memahami ajaran yang dibawa ulama' terdahulu. Kitab kuning ini termasuk suatu karya didalam bertulisan Bahasa arab yang ditulis oleh sarjana islam sekitar abad pertengahan, yang sering disebut dengan kitab kuno. Pembelajaran kitab kuning menjadi hal tersendiri dalam jiwa santri. Hal tersebut agar setiap santri mampu mengimplementasikan dan mengamalkan apa yang ada dalam kitab klasik tersebut. Seperti yang dikatakan pepatah lama, dalam mencari ilmu dimulailah dari sejak dini (kecil) karena belajar diwaktu kecil bagaikan meengukir diatas batu. Jika hal tersebut disandangkan pada santri, maka santri mampu menghadapi zaman yang semakin maju untuk menjadi lebih baik lagi hidup selanjutnya. Seorang santri merupakan penerus pewaris ulama' dalam menyampaikan wasilah dari pendahulu.

Dalam pembelajaran kitab klasik tersebut terdapat beberapa metode diantaranya: metode sorogan, metode bandongan, metode hafalan dan metode demonstrasi/praktik. Metode yang digunakan Pondok Pesantren Nurul Jadid khusunya wilayah Fatimatuzzahro' yaitu, metode sorogan. Metode sorogan ini seorang santri membaca terlebih dahulu kitab secara perorangan yang langsung berhadapan dengan guru untuk mengetahui kemampuan setiap santri. Pembelajaran kitab yang dipelajari di wilayah Fatimatuzzahro' diantaranya: kitab taisirul khalak, washoyatul abai wal abna', ta'limul mutaallim, fathul qarib. Dalam kita tersebut terdapat beberapa hadis, hukum dan akhlak kepada guru dan kedua orang tua, sebagai ilmu yang bisa diamalkan jika sudah terjun dimasyarakat.

Hidden kurikulum yang dilaksanakan pondok pesantren Nurul Jadid khususnya wilayah Fatimatuzzahro' tidak hanya dengan adanya pembelajaran kitab klasik saja, melainkan ada juga program madrasah diniyah. Madrasah diniyah di fatimatuzzahro' ini mempunyai beberapa tingkatan, adapun tingkatan siswi diniyah fatimatuzzahro' terdiri dari tiga bagian bagi siswi diantaranya: Awwaliyah, Wustho, Ulya. Awwaliyah ini merupakan tingkatan pertama madrasah diniyah fatimatuzzahro', yang mana tingkatan pertama ini santri akan menempuh pembelajaran selama tiga tahun. Tingkatan pertama santri akan mempelajari beberapa kitab 
diantaranya: fathul qorib, sorrof, ilmu tafsir, khulasoh nurul yakin. Wustho merupakan tingkatan kedua yang mana pembelajaran akan ditempuh satu tahun. Begitu juga dengan tingkatan ketiga santri akan melakukan pembelajaran selama satu tahun. Dengan semakin berkembangnya zaman, wilayah fatimatuzzahro' menambah dua tingkatan lagi, yang mana dalam hal ini pada tahun 2020 madrasah diniyah fatimatuzzahro' menambah program baru, program madrasah diniyah ini dinamai dengan DPK (diniyah program khusus), DPK ini merupakan program baru wilayah fatimatuzzahro' yang mana pembelajaran dilakukan oleh beberapa mahasiswi, dalam pembelajaran DPK ini santri (mahasiswi) akan mempelajari beberapa kitab salah satunya tentang fiqh munakahat, fiqh muamalah dll. Adanya pembelajarn madrasah diniyah merupakan salah satu tameng dalam membentuk perilaku pekerti yang ada pada diri santri, dengan melalui pembelajaran yang telah disebutkan diatas ${ }^{32}$.

Melalui beberapa kegiatan yang telah disebutkan tadi yang sudah diterapkan di wilayah Fatimatuzzahro', maka dapat diambil manfaat setiap santri serta diamalkan isinya. Sehingga dapat diterapkan santri dalam kehidupan setiap harinya. Dengan adanya kegiatan tersebut santri akan bertindak sesuai dengan aturan agama. Manfaat kegiatan tersebut diantaranya: pertama, memberikan pengaruh yang positif terhadap santri agar bertingkah laku lebih baik lagi dari pada sebelumnya. Kedua, melatih santri agar tidak melanggar karena perbuatan yang dilakukan dipesantren merupakan suatu cerminan kelak dimasyarakat. Ketiga, guru memberikan aturan kepada santri itu bukan karena tidak senang ataupun membencinya melainkan demi kebaikan santri sendiri. Keempat, santri merupakan suatu keteladanan bagi masyarakat. Oleh sebab itu, pesantren mengimplementasikan pembelajaran kitab klasik agar setiap santri dalam bertingkah laku atau perilaku yang kurang baik itu bisa berubah sedikit demi sedikit sesuai dengan lingkungan yang ada, baik di masyarakat maupun dipesantren.

\section{Kesimpulan}

Perilaku pekerti merupakan permasalahan yang sangat penting sekali dalam kehidupan manusia karena dengan kurangnya moral dalam diri seseorang, maka akan membuat orang itu bertingkah laku kurang sopan. Pesntren merupakan suatu wadah bagi seseorang untuk meningkatkan ilmu agamanya. Sehingga pesantren mengimplementasikan Pendidikan

\footnotetext{
32 Hasil wawancara dengan salah satu pengurus Madrasah Diniyah Fatimatuzzahro' tanggal 17 November 2020 Pukul 10.00 Wib.
} 
religius kepada santri yang merupakan dasar kehidupan manusia dimuka bumi yang harus tertanam dalam diri seseorang khususnya santri.

Penanaman karakter yang dilakukan diwilayah Fatimatuzzahro' dalam membentuk perilaku pekerti santri dengan melalui beberapa metode penanaman karakter bersifat religius. Adapun suatu yang bersifat religius ini dengan melalui beberapa kegiatan di wilayah fatimatuzzahro' diantaranya: pertama pembiasaan (habbituasi) seperti shalat tahajjud, shalat dhuha serta tidak lupa shalat lima waktu secara berjamaah, kedua good example (keteladanan), seperti halnya penanaman akhlak sebagai teladan bagi santri dengan melalui tausiyah yang guru berikan, ketiga hidden kurikulum merupakan hal sangat penting untuk menambah pengetahuan santri. Dengan adanya beberapa metode yang sudah dijelaskan diatas mengenai kegiatan pondok pesantren nurul jadid khususnya wilayah fatimatuzzahro' merupakan tameng bagi santri yang mempunyai moral kurang baik.

\section{Daftar Pustaka}

Anam, Saeful, and Muhammad Sidiq Jaelani, 'ISLAMIC SCHOOL CULTURE DAN UPAYA MENANAMKAN NILAI-NILAI RELIGIOUS DI SMP ISLAMIC QON GRESIK', 2018, 551-60

Baharun, Hasan, and Zulfaizah, 'Revitalisasi Pendidikan Agama Dalam Pembentukan Karakter Peserta Didik Di Madrasah', ELEMENTARY, 6.1 (2018), 43-62

Bahri, Saiful, 'IMPLEMENTASI PENDIDIKAN KARAKTER DALAM MENGATASI KRISIS MORAL DI SEKOLAH', TA'ALLUM, 3.1 (2015), 57-76

Candra, Pasmah, Nelly Marhayati, and Wahyu, 'PENDIDIKAN KARAKTER RELIGIUS DAN TOLERANSI PADA SANTRI PONDOK PESANTREN AL HASANAH BENGKULU', 11.1 (2020), 111-32

Chusnul Muali, 'RASIONALITAS KONSEPSI BUDAYA NUSANTARA DALAM MENGGAGAS PENDIDIKAN KARAKTER BANGSA MULTIKULTURAL', Jurnal Islam Nusantara, 1.1 (2017), 105-17

Dahlan, Muhtar Zaini, 'INTERNALISASI PENDIDIKAN KARAKTER', FALASIFA, 7.1 (2016), 155-72

Dulkiah, Moh, and Muhammad Dachlan, 'MODEL PENGEMBANGAN KARAKTER SANTRI DI PESANTREN PERSIS 67 BENDA TASIKMALAYA JAWA BARAT', Jurnal Al-Qalam, 24.1 (2018), 177-88 
Fathoni, Tamrin, 'PESANTREN DAN PENANAMAN SIKAP ANTI KORUPSI', AL-MANHAJ; Jurnal Hukum Dan Pranata Sosial Islam, 1.1 (2019), 26-42

Fitriyah, Lailatul, and Erfi Fitri Wahyuni, 'HANDLING SPIRITUALISM SEBAGAI KONTROL DIRI PADA REMAJA DI PONDOK PESANTREN', Jurnal Islam Nusantara, 4.1 (2020), 1-16

H. Abdul Rahman, 'PENDIDIKAN AGAMA ISLAM DAN PENDIDIKAN ISLAM - TINJAUAN EPISTEMOLOGI DAN ISI - MATERI', JURNAL EKSIS, 8.1 (2012), 2053-59

Hambal, Muhammad, 'Pembentukan Karakter Rabbani Di Pesantren AlIslam Lamongan Jawa Timur Indonesia', Jurnal Tadarus, 8.1 (2019), $74-82$

Khaliq, Abd, 'PENDIDIKAN KARAKTER DALAM PERSPEKTIF KITAB AYYUHAL WALAD; KONSTRUKSI PEMIKIRAN IMAM AL-GHAZALI', Al-Ibrah, 2.1 (2017), 89-112

Listrianti, Feriska, and Fitriana, 'PENDIDIKAN AKHLAK PERSPEKTIF AL-GHAZALI DALAM MENGATASI RATIONAL HEDONISM DI MTS NEGERI 1 PROBOLINGGO', RIS ALAH Jurnal Pendidikan Dan Studi Islam, 6.1 (2020), 100-116

Mahmudah, Hasan Baharun and, 'KONSTRUKSI PENDIDIKAN KARAKTER DI MADRASAH BERBASIS PESANTREN', Jurnal MUDARRISUNA, 8.1 (2018), 149-73

Makmun, H.A. Rodli, PEMBENTUKAN KARAKTER BERBASIS PENDIDIKAN PESANTREN: Studi Di Pondok Pesantren Tradisional Dan Modern Di Kabupaten Ponorogo', Cendekia, 12.2 (2014), 212-37

Manan, Syaepul, 'PEMBINAAN AKHLAK MULIA MELALUI KETELADANAN DAN PEMBIASAAN', Jurnal Pendidikan Agama Islam-Ta'lim, 15.1 (2017), 49-65

Marzuki, and Pratiwi Istifany Haq, PENANAMAN NILAI-NILAI KARAKTER RELIGIUS DAN KARAKTER KEBANGSAAN DI MADRASAH TSANAWIYAH AL FALAH JATINANGOR SUMEDANG', Jurnal Pendidikan Karakter, VIII.1 (2018), 84-94

Muali, Chusnul, Ayyul Fariqoini, and Azizatul Widad, Pembelajaran Konstruktif (Pustaka Nurja, 2019)

Muali, Chusnul, and Putri Naily Rohmatika, 'KAJIAN REFLEKSI TEORI PENGEMBANGAN KARAKTER ANAK MELALUI PEMBELAJARAN AGAMA PERSPEKTIF ALBERT BANDURA', FIKROTUNA; Jurnal Pendidikan Dan Manajemen Islam, 9.1 (2019), 1032-52 
Mubarok, Ahmad Zakky, 'Model Pendekatan Pendidikan Karakter Di Pesantren Terpadu', Ta'dibuna, 8.1 (2019), 134-45

Mumtahanah, Nurotun, 'PENGEMBANGAN SISTEM PENDIDIKAN PESANTREN DALAM MENINGKATKAN PROFESIONALISME SANTRI', AL HIKMAH Jurnal Studi Keislaman, 5.1 (2015), 55-70

Mundiri, Akmal, and Irma Zahra, 'CORAK REPRESENTASI IDENTITAS USTADZ DALAM PROSES TRANSMISI PENDIDIKAN KARAKTER DI PESANTREN', 2005, 21-35

Nofiaturrahmah, Fifi, 'METODE PENDIDIKAN KARAKTER DI PESANTREN', Pendidikan Agama Islam, XI.1 (2014), 201-16

Setyawati, and Zakiyah, PELATIHAN PENCEGAHAN MEROSOTNYA MORAL SANTRI MELALUI BELAJAR SEKSUALITAS DENGAN KAJIAN KITAB KUNING DAN KESEHATAN REPRODUKSI REMAJA DI PONDOK PESANTREN ROMLAH ASSOMADIYAH KECAMATAN CILONGOK', ISLAMADINA, XVII.2 (2016), 21-30

Suhardi, Didik, 'PERAN SMP BERBASIS PESANTREN SEBAGAI UPAYA PENANAMAN PENDIDIKAN KARAKTER KEPADA GENERASI BANGSA', Jurnal Pendidikan Karakter, II.3 (2012), 316-28

Supardi, Didi, Abdul Ghofar, and Mahbub Nuryadien, 'KONSEP PENDIDIKAN MORAL IMAM AL-GHAZALI DAN RELEVANSINYA DENGAN PENDIDIKAN AGAMA ISLAM DI INDONESIA', JURNAL AL TARBAWI AL HADITS AH, 1.2, 1-9

Ulum, Miftachul, 'PEMBENTUKAN KARAKTER MELALUI PENDIDIKAN BERBASIS PONDOK PESANTREN', EVALUASI, 2.2 (2018), 382-97 